\title{
Incidental Isolated fibrolipoma of Filum Terminale in Adult
}

Mukesh Kumar Gupta, Raj Kumar Rauniyar, Kanchan Dhungel,

Kaleem Ahmad, Sajid Ansari

From the Department of Radiodiagnosis \& Imaging, B. P. Koirala

Institute of Health Sciences, Dharan, Nepal.

\section{Abstract:}

Fibrolipomas of the filum terminale are embryonic in origin and are seen on MR images as small areas of fatty tissue along the filum terminale. These lipomas may result from faulty retrogressive differentiation. Though the lesions are frequently asymptomatic, fibrolipomas are a known cause of cord tethering and the tight filum syndrome. We present a case of isolated fibrolipoma of the filum terminale in an adult male which was detected incidentally on MRI done for evaluation of disc herniation.

Key words: CaudaEquina, Lipoma, Magnetic Resonance Imaging, Intervertebral Disc Displacement.

\section{Introduction}

Fibrolipoma of the filum is an error in development of the caudal cell mass which differentiates towards adipose tissue to form lipoma. Presence of fatty signal (hyperintense on $\mathrm{T} 1 \mathrm{~W} 1$ ) in the filum terminale, referred as fatty filum, may be observed incidentally in up to $5 \%$ of normal adults and is considered a normal variation if it is not associated with cord tethering or neurologic dysfunction [1]. Diagnosis of filum terminale lipoma should be made when fatty filum is thicker than $2 \mathrm{~mm}[2,3]$. Though the lesions are frequently asymptomatic, fibrolipomas are a known cause of cord tethering and tight filum syndrome. In such cases it is usually associated with a thickened filum and a low lying conus medullaris [4]. The aim of our report is to present an incidentally detected isolated fibrolipoma of the filum terminale in an adult undergoing MRI evaluation for disc herniation.

\section{Case Report}

We present a case of 52-year-old male with history of low back pain for one month. Neurological and other systemic findings were unremarkable. A diagnosis of disc herniation was made on clinical ground and the patient was referred for MRI evaluation of lumbosacral spine. MRI revealed degenerative changes with disc herniation at L4-L5 \& L5-S1 levels. An incidental finding was observed as a linear high signal area of thickness $3.4 \mathrm{~mm}$ on $\mathrm{T} 1 \mathrm{~W} 1$ [Fig. 1,2 \& 3] within the intradural part of filum terminale extending from L2 to L5 vertebral level, suggesting fibrolipoma of filum terminale. However, the position of the conus medullaris was seen at normal L1-L2 level. No any other congenital anomaly was observed on MRI spine.

\section{Corresponding Author: Dr. Mukesh Kumar Gupta}

Email: mukeshgupta148@yahoo.com

Received: March 19, 2013 | Accepted: April 12, 2013 | Published Online: April 30, 2013

This is an Open Access article distributed under the terms of the Creative Commons Attribution License (creativecommons.org/licenses/by/3.0)

Conflict of interest: None declared | Source of funding: Nil | DOl: http://dx.doi.org/10.17659/01.2013.0031 


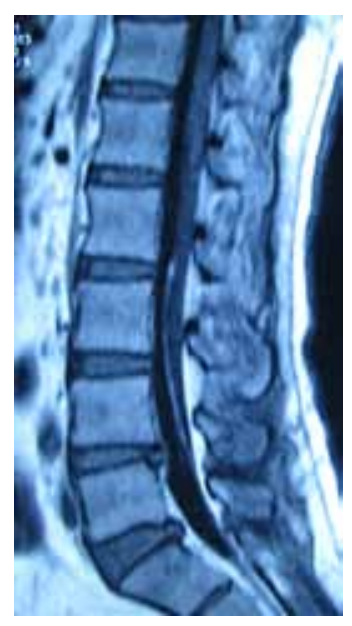

Fig.1: Sagittal TIW image shows a linear high signal area of thickness $3.4 \mathrm{~mm}$ within the intradural portion of filum terminale suggesting fibrolipoma of filum terminale. The conus medullaris is seen at normal position with no evidence of tethering. Disc herniation is revealed at L4-L5 \& L5-S1 levels.

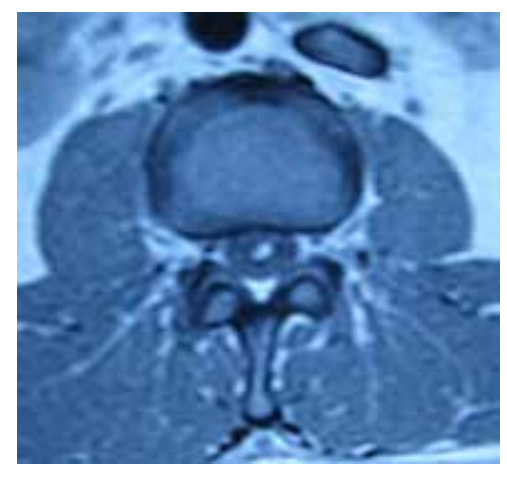

Fig.2: Axial TIW image shows mildly thickened intadural filum with high signal fat within it.

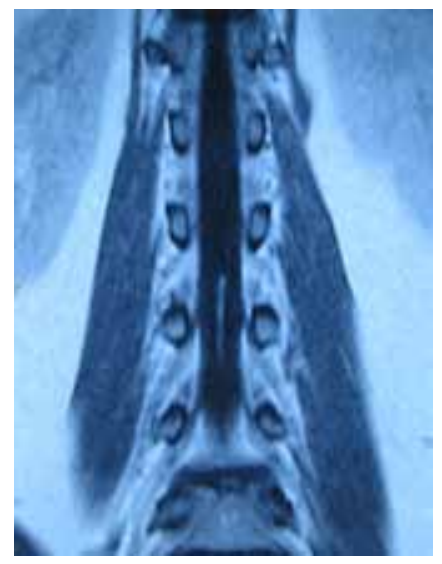

Fig.3: Coronal T1W image shows linear high signal area of fat in the intradural part of filum terminale. 


\section{Discussion}

Fatty infiltration of the filum has been reported in $6 \%$ of autopsy specimens and therefore if found incidentally on MR is usually considered a normal variation when the filum is not enlarged and the conus is in normal position [5]. Uchino et al found four cases of thickened fatty filum terminale in 1,691 MR scans but regarded them as incidental because the conus was in the normal position and the patients' symptoms were judged to be unrelated [6]. In our case also there was thickened fatty filum but the conus was at normal position and the patient's symptom was judged to be unrelated to this entity, so it was considered to be an incidental finding. The low back pain in our patient was well explained by presence of degenerative changes and disc herniation. Fat in the filum may represent mesodermal cells that did not properly migrate to their normal position in the process of canalization. The presence of fatty tissue may alter the developmental properties of the filum and may predispose to cord tethering [7]. Tight filum terminale syndrome is a complex of neurologic and orthopedic deformities associated with a short, thick filum terminale and low lying conus medullaris with variable clinical manifestations [8]. Pain, dysesthesias, neurogenic bladder and spasticity are the common clinical presentations of tethered cord and tight filum terminale [4]. Kyphoscoliosis is seen in $15 \%$ to $25 \%$ of these cases [9]. A filar lipoma appears as a hyperintense strip of signal on T1-weighted MR images within the thickened filum terminale. Filar lipomas may involve the intradural, the extradural or both portion of the filum. The intradural filar lipomas tend to be fusiform and taper down towards the point where the filum pierces dura, while the extradural filar lipomas are far more diffuse, larger, and tend to merge with adjacent extradural fat [9]. In our case, the intradural part of the filum terminale was involved which appeared as a linear hyperintense signal on T1W images.

\section{Conclusion}

Presence of fat in the filum terminale may be an incidental finding of no clinical concern and can be considered a normal variation if it is not associated with cord tethering or neurologic dysfunction.

\section{References}

1. Brown E, Matthes JC, Bazan C 3rd, Jinkins JR. Prevalence of incidental intraspinal lipoma of the lumbosacral spine as determined by MRI. Spine. 1994;19:833-836.

2. McLendon RE, Oakes WJ, Heinz ER, Yeates AE, Burger PC. Adipose tissue in the filum terminale: a computed tomographic finding that may indicate tethering of the spinal cord. Neurosurg. 1988;22:873876.

3. Okumura R, Minami S, Asato R, Konishi J. Fatty filum terminale: assessment with $M R$ imaging. J Comput Assist Tomogr. 1990;1 4:571-573.

4. Raghavan N, Barkovich AJ, Edwards M, Norman D. MR imaging in the tethered spinal cord syndrome. Am J Roentgenol. 1989;152:843-852.

5. Emery JL, Lendon RG. Lipomas of the cauda equina and other fatty tumors related to neurospinal dysraphism. Dev Med Child Neurol Suppl. 1969;20:62-70.

6. Uchino A, Mori T, Ohno M. Thickened fatty filum terminale: MR imaging. Neuroradiology. 1991;33:331 333. 
7. Bulsara KR, Zomorodi AR, Enterline DS, George TM. The Value of Magnetic Resonance Imaging in the Evaluation of Fatty Filum Terminale. Neurosurgery. 2004;54:375-380.

8. Naidich TP, McLone DG, Harwood-Nash DC. Spinal dysraphisms. In: Newton TH, Potts DG, (eds). Computed tomography of the spine and spinal cord. San Anselmo: Clavadel Press; 1983. pp.299-353.

9. Naidich TP, Blaser SI, Delman BN, et al. Congenital Anomalies of the Spine and Spinal Cord: Embryology and Malformations. In: Atlas SW eds. Magnetic Resonance Imaging of the Brain and Spine, 4th ed. Philadelphia: Lippincott Williams \& Wilkins; 2009. pp.1364-1447. 